\section{MWCARE PLATFORM - LÉKAŘSKÝ INFORMAČNÍ SYSTÉM BUDOUCNOSTI}

\section{Jiří Potůček, Nikola Tomková, Lenka Lhotská, Jaromír Doležal}

\section{Anotace}

Platfroma MWCare je komplexní webové informační řešení pro poskytování telemedicínských dohledových služeb a asistenčních služeb pro domácnosti. $V$ neposlední řadě umožňuje ukládaní a přístup k zdravotním datům pacienta a ukládání potřebných údajů při návštěvě i mimo ordinaci lékaře. Platforma poskytuje nejlepší řešení pro domácí vyšetření, diagnostiku a primární léčbu bez čekání. Pacienti si mohou snadno zkontrolovat svůj zdravotní stav doma a poskytují lékařům potřebné údaje. Lékaři mohou zkontrolovat všechny monitorované údaje vybraného pacienta na jednom místě a mohou zahájit videokonzultaci ve vhodnou dobu pro pacienta.

\section{Klíčová slova}

telemedicína, telemedicínská platforma, moduly, dávkovaní léčiv, optimalizovaná farmakoterapie

\section{1 Úvod}

Platforma MWCare je novinkou pro lékaře při fyzické návštěvě či při virtuálním vyšetření $z$ domácího prostředí. MWCare je komplexní webové informační řešení pro poskytování telemedicínských dohledových služeb a asistenčních služeb pro domácnosti. $V$ neposlední řadě umožňuje ukládání a přístup k zdravotním datům pacienta a ukládání potřebných údajů při návštěvě i mimo ordinaci lékaře.

\section{Platfroma MWCare}

Základem platformy MWCare je modul „TELECONSULTATION“ $s$ částí Medical book - nová verze projektu bývalého projektu Medicus (Informační systém pro soukromé praxe a polikliniky). $\mathrm{K}$ této platformě byl následně připojen původní modul „TELE-
PHARMACOLOGY“, který byl v minulosti využíván pro konsilia klinických farmaceutů a farmakologů a dál různými moduly pro měření fyziologických signálů $v$ domácím prostředí (EKG, teplota tlak, glykémie, SPO2...), jeho ukládání a zpracování v centrálním serveru nejen pro evidenci zdravotnických údajů pacienta, ale i s možnosti dalšího zpracování těchto signálů pro vědecké účely. Nová platforma MWCare je v současné době nasazena u našeho partnera v Káhiře (Egypt) a probíhá zkušební provoz.

Dle našeho názoru jde o platformu, kterou Ize označit jako MEDICUS NOVÉ GENERACE (informační systém lékaře nové generace), který bude sloužit nejen jako základní informační systém, ale umožní a usnadní komunikaci z domácího prostředí zejména pro pacienty s chronickými onemocněními, psychiatrické pacienty apod.

Významnou částí se stal i projekt Personal Genetic Card, který umožňuje zahrnout do léčebného procesu i genetické anomálie a vady konkrétního pacienta, což je zásadní zejména z hlediska metabolismu léčiv (farmakogenomika). Ve využití automatizovaného způsobu volby medikace spatřujeme zásadní kvalitativní krok.

Z tohoto hlediska vidíme platformu MWCare jako nástroj budoucnosti pro lékařské praxe a kliniky a zároveň i př́klad tzv. znalostní ekonomiky (viz P. F. Drucker - Fungující společnost). Z tohoto důvodu vývoj a rozvoj systému patří k hlavní náplni firmy Mediware a.s., která má všechny potřebné certifikáty k vývoji zdravotnického systému a spolupracuje $s$ distribuční a marketingovou firmou MWCare, která vrací potřebné znalosti a potřeby z privátních organizací a poliklinik zpět do produktu platformy MWCare.

Platforma MWCare tvoři základ budoucí práce privátních lékařŭ, odborných lékařů a klinických farmakologů. Zvláštní zřetel věnujeme proto rozvoji této platformy nejen pro lékařskou obec, ale i pro potřeby domácí péče, kde vidíme rovněž velké budoucí využití.

V souvislosti s modulem „TELEPHARMACOLOGY“ jsme se stali lídry v novém oboru nazývaném Model Informed Precision Dosing - MIPD a získali jsme pro část TDM první místo v roce 2013 při srovnávací studii prováděné ve Švýcarsku [1,2] - první až druhé místo - viz príslušné citace.

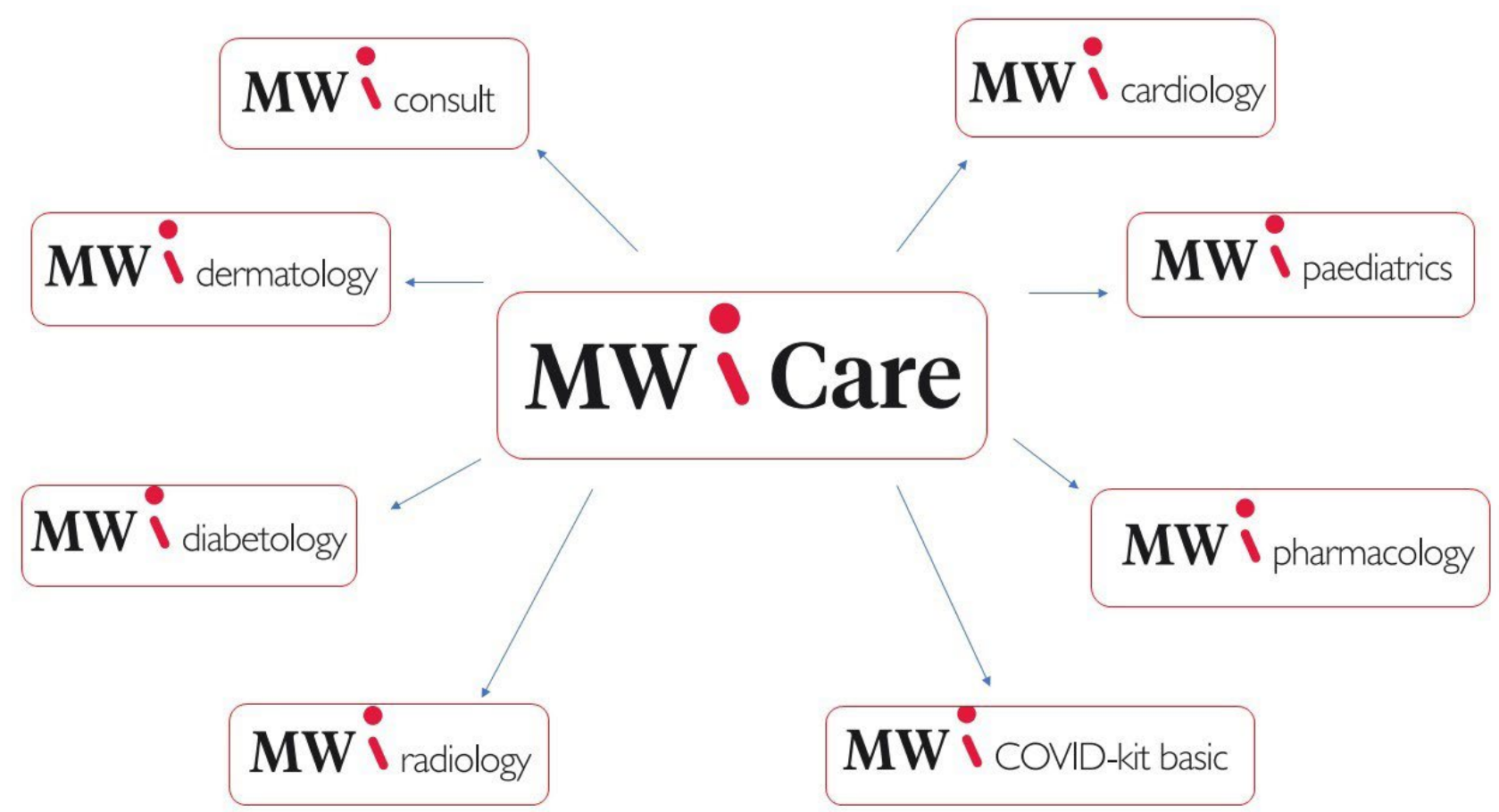

Obrázek 1 - Schéma platfromy MWCare 
V oblasti MIPD si produkt MWPharm dělí světový trh pouze $s$ produktem InsightRX z Kalifornie. (Tato firma získala pro rozvoj MIPD venture capital ve výši 10M USD v minulém roce.)

Pro marketingové a výukové účely stojí za zmínku též vznikající učebnice a výuková pomůcka pro oblast Model Informed Precision Dosing - MIPD, která je hlavní náplní grantového projektu - Nadstavbová platforma PBPK TRIO FV40426, který řešíme společně s CIIRC CVUT.

Tento projekt bude dokončen v príštím roce a bude sloužit k výuce na lékařských, farmaceutických a bioinženýrských fakultách ve více než 30 zemích, kde je MWPharm dosud používán. Předpokládáme, že tato výuka nejvíce pomůže marketingu a tím rozšíŕení MIPD přistupu pomocí projektu MWPharm do reálné praxe.

\section{Popis modulů platfromy MWCare}

\subsection{Medical Book}

Veškerá lékařská dokumentace pacienta je $\mathrm{k}$ dispozici online v jednom cloudovém úložišti. Zodpovědný lékař má 24hodinový př́stup. Toto řešení je vhodné pro virtuální i pro domácí vyšetření. Medical book obsahuje veškerou klinickou historii pacienta, jako jsou informace o životním stylu, rizikové faktory, alergie, historie léků, recepty, laboratorní a radiologické vyšetření.

\subsection{Telekonzultace}

Cílem telekonzulace je spojit pacienta s lékařem pohodlným, bezpečným a chytrým způsobem s využitím nejnovějších dostupných technologií. Platforma poskytuje nejlepší řešení pro domácí vyšetření, diagnostiku a primární správu bez čekání.

Pacient může svůj zdravotní stav konzultovat se svým lékařem prostřednictvím audiovizuálního hovoru pomocí notebooků, tabletů, iPadů, chytrých telefonů atd. Kromě toho je v rámci platformy $\mathrm{k}$ dispozici také chat. Pacienti mohou také snadno kontrolovat svůj zdravotní stav doma a poskytovat svým lékařům požadované údaje.

Telekonzultace má pro oba partnery několik výhod /pacient a poskytovatel zdravotní péče/:

- Snižuje riziko šíření infekce - je ideálním řešením pro péči o pacienty v karanténě, napríklad o pacienty COVID.

- Chránit poskytovatele zdravotní péče

- Lékařské záznamy jsou na jednom úložném místě a jsou vždy k dispozici. Lékař má veškerou zdravotní dokumentaci pacienta $\mathrm{k}$ dispozici online $\mathrm{v}$ jednom úložném cloudu.

- Vhodné pro virtuální návštěvu lékaře i pro domácí vyšetření

- Přehled anamnézy pacienta na jedno kliknutí

- Zasílání lékařských předpisů

- Úspora času (čekání v čekárně ...)

- Možnost mít rodinné účty - rodiče mají přehled o zdravotních záznamech svých dětí

- Platforma umožňuje sledování životních funkcí pacienta

- Snadné objednávání - at' už na online konzultaci, nebo na osobní fyzickou návštěvu

- Monitorování různých parametrů u chronických pacientů - zajištění nepřetržitého sledování chronicky nemocných pacientů

- Odesílání souborů na zabezpečené platformě

- Videokonference pro více uživatelů umožňuje komunikaci praktického lékaře, pacienta i specialisty pro druhý názor.

\subsection{Dohled}

Cílem služby je snízit zdravotní a sociální rizika starých nebo zdravotně postižených lidí a umožnit jim žít $v$ jejich vlastním sociálním prostředí.

Klienti využívající službu „Dohled“ jsou vybaveni mobilním dohledovým zařízením. Stisknutím SOS tlačítka na dohledovém zařizení může klient oznámit stav nouze asistenčnímu dohledovému centru, s operátorem může pomocí dohledového zařízení obousměrně hlasově komunikovat, operátor může zjistit aktuální zeměpisnou polohu dohledového zařízení a zajistit vhodný typ pomoci klientovi. Dohledové zařízení dále umožňuje automaticky upozornit asistenční dohledové centrum na možný pád klienta. $\mathrm{K}$ systému MWCare, resp. $\mathrm{k}$ údajům o klientovi a jeho řešených nouzových událostech, může mít přístup jak samotný klient, tak jím oprávněné kontaktní osoby.

Webová platforma MWCare je k dispozici v mnoha jazycích a na vyžádání ji Ize přeložit do jazyka dle vašeho výběru.

Předpokládanými prínosy využití služby „Dohled“ je zvýšení samostatnosti, soběstačnosti, bezpečnosti a tím i kvality života seniorů žijících v domácím prostředí a také delegování odpovědnosti za dohled nad seniory z rodinných př́slušníků na asistenční dohledovou službu.

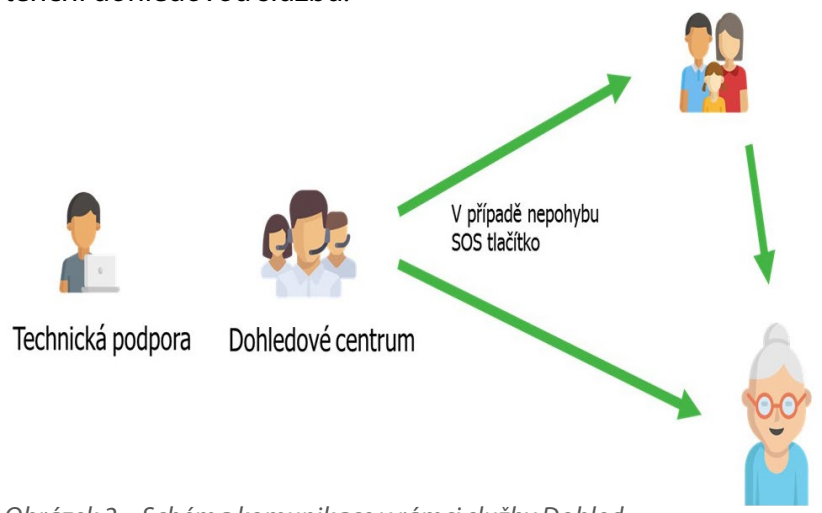

Obrázek 2 - Schéma komunikace v rámci služby Dohled

Bez ohledu na cílovou skupinu můžeme Tísňovou péči definovat jako komplexní sociální službu, která pomocí nepřetržité distanční hlasové a elektronické komunikace monitoruje aktivně nebo pasivně uživatele/klienta služby $v$ jeho bytě či venku. Pouze záleží na typu zvoleného koncového zařízení tísňové péče, kterým si klient může přivolat potřebnou pomoc. $V$ případě náhlého zhoršení zdravotního stavu nebo schopností, či jiné krizové situace tísňová péče.

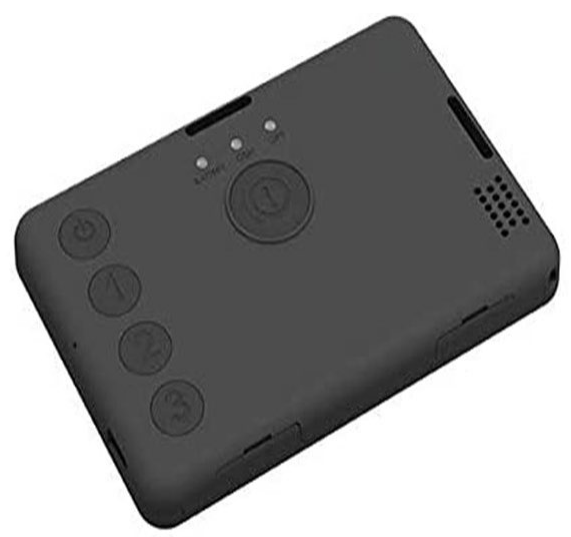

Obrázek 3 - Zařízení využívané v službě Dohled - Teltonika 


\subsection{Tele-kardiologie}

Tento modul je navržen pro vzdálenou péči o chronické srdeční pacienty. Pacienti si mohou objednat online konzultaci se svými kardiology. K dispozici jsou audio-vizuální konzultace i chat.

Kardiologové však mohou dokonce sledovat EKG svých pacientů pomocí několika připojených EKG zařízení, jako je například Polar nebo D-Heart.
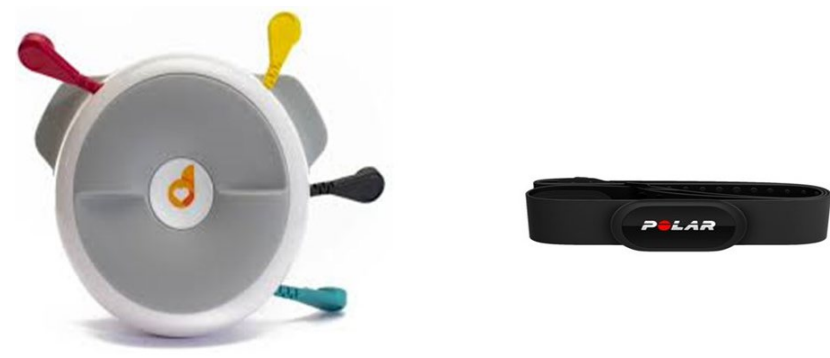

Obrázek 4 - Přístroje využívané v modulu telekardiologie - D-Heart, Polar

\subsection{Tele-pediatrie}

Tento modul je navržen pro vzdálenou péči o dětské pacienty $v$ rámci rodinného účtu. Tento modul pomáhá těmto pacientům při virtuální konzultaci s jejich pediatry, kteří nejsou schopni fyzické návštěvy. K dispozici jsou audio-vizuální konzultace i chat.

Všechny předchozí lékařské záznamy jsou uloženy $v$ tomto modulu a jsou vždy k dispozici poskytovateli zdravotní péče. Tělesnou teplotu Ize sledovat na dálku pomocí několika připoienv́ch teploměrů.

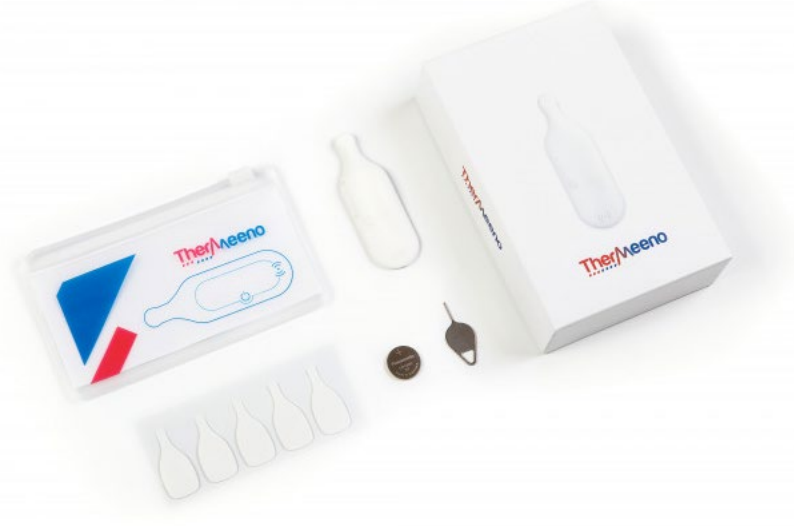

Obrázek 5 - Prístroje využívané v modulu telekardiologie - Thermeeno

\subsection{Tele-diabetologie}

Tento modul je určen $k$ péči o pacienty $s$ diabetes mellitus. Modul umožňuje pacientům absolvovat virtuální zvukovou, vizuální konzultaci a chat s jejich diabetology. Diabetologové nicméně mohou vzdáleně sledovat hladinu glukózy v krvi svých pacientů pomocí několika chytrých glukometrů.

Všechny sledované údaje a všechny lékařské záznamy pacientů jsou uloženy a jsou vždy k dispozici.

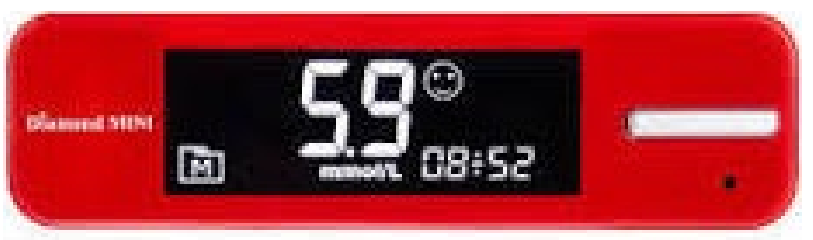

Obrázek 6 - Přistroje využívané v modulu telediabetologie - Glukometr Fora Diamond MINI

\subsection{Tele-dermatologie}

Tento modul je určen k péči o pacienty trpící kožními problémy. Modul pomáhá těmto pacientům absolvovat virtuální zvukovou, vizuální konzultaci a chat s jejich dermatology.

Všechna předchozí kožní vyšetření jsou bezpečně uložena, což dermatologům pomáhá při diagnostice i při sledování těchto pacientů.

V tomto modulu je poskytována HD kamera, která těmto pacientům usnadňuje dermatologické vyšetření. Proto jsou do našeho systému integrovány víceúčelové lékařské kamery, jako je Versascope. Fotoaparát je vybaven výměnnými objektivy, které mohou sloužit jako otoskop, rhinoskop a jsou vhodné pro vyšetření hrdla a dermatologické vyšetření.
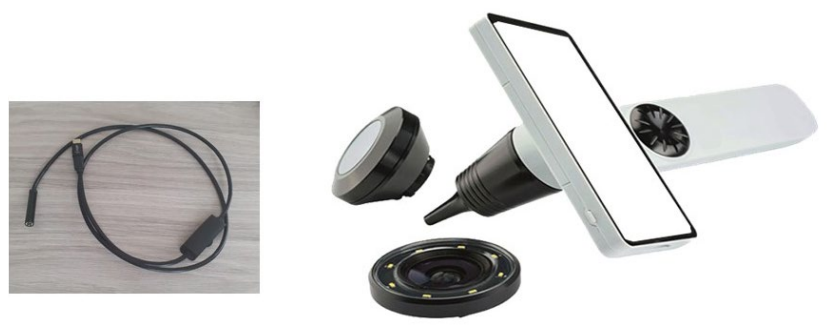

Obrázek 7 - Prístroje využívané v modulu teledermatologie - HD kamera, ORL kamera Versascope

\subsection{Tele-radiologie}

Platforma spojuje pacienta s lékařem a poskytuje nejlepší řešení pro konzultaci všech radiologických vyšetření provedených pacientem.

Nabízí pacientovi jediné bezpečné úložiště pro všechny radiologické snímky, které jsou pro poskytovatele zdravotní péče vždy $\mathrm{k}$ dispozici online.

\subsection{COVID-kit}

Tento modul byl navržen hlavně pro péči o pacienty se SARS-CoV-2. Poskytuje jim možnost zůstat v karanténě a v kontaktu se svými poskytovateli zdravotní péče. Tento modul umožňuje bezpečnou komunikaci pacienta i lékaře. K dispozici jsou audio-vizuální konzultace i chat.

Tento modul nicméně poskytuje poskytovatelům zdravotní péče sledování vitálních funkcí jako je tělesná teplota pomocí inteligentního teploměru a také kontrolu saturace krve kyslíkem pomocí moderního oxymetru. Tento modul je navíc vybaven HD kamerou pro vyšetření krku.

\subsection{0}

Nová technologická platforma, která pomáhá zdravotníkům s nejpokročilejším softwarovým nástrojem pro Drug Information System (DIS) a Model Informed Precision Dosing (MIPD).

Tele-Pharmacology podporuje celou optimální farmakoterapii požadovanou pro přesný elektronický předpis.

Tele-Pharmacology poskytuje zdravotnickým pracovníkům možnost sdílet obrazovku s MWpharmDIS, který zahrnuje jak Vidal Consult, tak i MWpharm ++.

Telefarmakologie poskytuje přístupnější a nákladově efektivnější aktualizované informace o léčivech a také poskytuje optimalizované individuální dávkování léků.

DIS využívá technologii Vidal Consult, která poskytuje kompletní referenční informace o lécích dostupných na trhu, pomáhá kontrolovat bezpečnost předpisu a umožňuje správu a optimalizaci nemocničních receptur.

MIPD využívá technologii MWpharm ++. Zahrnuje aplikaci matematických a statistických algoritmů využívajících simultán- 
ní integraci proměnných pacientů (tj. A priori predikce) a měření koncentrace jednotlivých léků (tj. A posteriori predikce nebo Bayesiánské předpovědi).

MIPD je často vnímán jako komplikovaný a časově náročný úkol. K překonání těchto překážek byly tyto modely implementovány do softwarových nástrojů na podporu klinického rozhodování o terapeutické individualizaci.

MIPD je dávkovací paradigma nové generace, $v$ němž se matematické modely pro léčivo a nemoci kombinují s individuálně měřenými kritérii pacienta (např. plazmatická koncentrace léčiva, genotyp, orgánová dysfunkce a charakteristiky nemoci). Systém MIPD je založen na softwaru MWpharm++. Zahrnuje aplikaci matematických a statistických algoritmů využívajících simultánní integraci kovariát pacienta (tj. apriorní předpověd) a individuálních měření koncentrace léčiva (tj. aposteriorní předpověd' nebo bayesovské prognózování). MIPD je často vnímána jako složitý a časově náročný úkol. $\mathrm{K}$ překonání těchto překážek byly tyto modely implementovány do softwarových nástrojů na podporu klinického rozhodování o individualizaci léčby.

Softwarový nástroj MIPD slouží k optimalizaci dávkovacích režimů těchto pacientů pomocí matematických a statistických algoritmů, které zohledňují tyto individuální kovariáty těchto pacientů (věk, hmotnost, funkce jater, funkce ledvin a genotyp).

Zdravotničtí pracovníci kdekoli mohou získat přistup k tele-farmakologii, aby zkontrolovali poslední aktualizované informace o určitém léku, vedlejších účincích, kontraindikacích, zkontrolovali recepty na jakoukoli lékovou interakci a také zkontrolovali optimalizovanou a priori a a posteriori predikci jednotlivých dávek jejich pacientů.

\section{Popis projektu MwPharm}

Projekt MwPharm/Telepharmacology byl dosud využíván pouze v klinickém provozu nemocnic (JIP, nefrologická odd., onkologie, ale i pediatrie a další). V tomto roce se použití MWPharmu rozšiřilo s využitím přibližně 50 nejběžnějších léčivých látek i pro praktického a dětského lékaře.
Pomocí „populačních PKPD modelů nejběžnějších léčivých látek" vznikla metodika, jak i praktický a dětský lékař může redukovat dávku pro pacienta s různým typem anomálií (obézní pacienti, pacienti s poškozením ledvin nebo jater, kojenci - zejména nedonošení...). Tato pomůcka rozšiřuje použití projektu MWPharm o novou klientelu - praktických a dětských lékařů a rozšiřuje tak komerční potenciál projektu MwPharm (SMART CALCULATOR).

Při využívaní služby TELEPHARMACOLOGY jsme získali inspirující zpětné vazby od koncových uživatelů projektu MWPharm, klinických farmakologů a farmaceutů, praktických lékařů a dětských lékařŭ,

kteří požadovali mít v jednom systému všechny informace, které slouží k rozhodováni o správném dávkování léčiva pro daného pacienta. Celý systém pak Ize popsat blokovým schématem (Obr. 8) moduly: Vidal Consulting, "A priory dosing" pomocí našeho Smart Calculator, A posteriory dosing v procesu TDM pomoci MWPharm(/. Byla vytvořena i spolupráce s nadnárodní firmou VIDAL. Odkaz na Vidal Consulting se stal součástí MWPharm DIS, který umožňuje koncovému uživateli - lékaři zajistit všechny potřebné informace o dané léčivé látce včetně základních doporučení dávkování. MWPharm potom doplňuje tuto funkčnost o případy, kde je nutno změnit / redukovat počáteční dávku léčiva pro daného anomálního pacienta - obezita, neonate.../ schéma dávkování v ordinaci praktického či dětského lékaře. Zároveň při možnosti měření koncentrace podaného léčiva pacientovi během klinického procesu organizovaně měnit dávku léčiva během léčebného procesu v nemocnici pomocí MWPharm (A postetriory dosing).

\section{Závěr}

Platforma spojuje pacienta s lékařem a poskytuje nejlepší řešení pro domácí vyšetření, diagnostiku a primární léčbu bez čekání. Platforma pro telemonitoring pokrývá širokou škálu monitorování a je otevřená novým službám. Pacienti si mohou snadno zkontrolovat svůj zdravotní stav doma a poskytují lékařům potřebné údaje. Lékaři mohou zkontrolovat všechny monitorova-

\section{Model Informed Precision Dosing}

\section{Education}
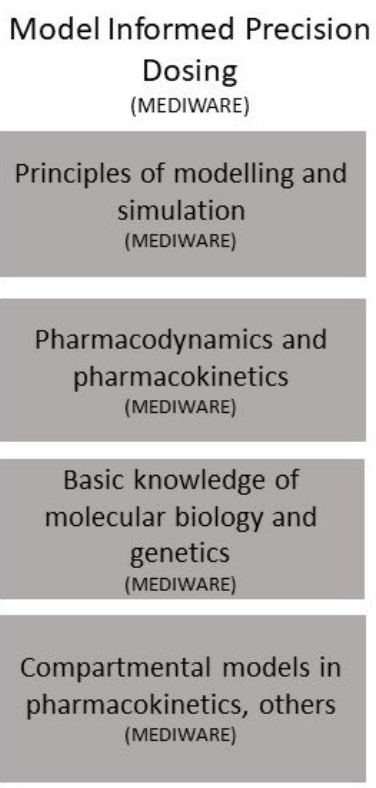

\section{Clinical process}

A priori dosing

Informations about drug (SPC, PIL, ...) (VIDAL)

\section{Electronic} prescription

Contraindications (VIDAL)
A posteriori dosing

TDM

(MwPharm)
Genetic module

(MwPharm) 
né údaje vybraného pacienta na jednom místě a mohou zahájit videokonzultaci ve vhodnou dobu pro pacienta.

Každou službu Ize poskytovat samostatně nebo jako kombinaci vybraných modulů. MWCare nabízí lékařum analýzu dat a moderní certifikované měříí nástroje. Uživateli platformy jsou napríklad - pacienti, senioři v domácím prostředí, lékaři, chroničtí pacienti, kriticky nemocní pacienti, sociální pracovníci a rodinní príslušníci.

\section{Literatura}

[1.] FUCHS, Aline, Chantal CSAJKA, Yann THOMA, Thierry BUCLIN a Nicolas WIDMER. Benchmarking Therapeutic Drug Monitoring Software:a pro MIMD Review of Available Computer Tools. Clinical Pharmacokinetics [online]. 2013, 52(1), 9-22 [cit. 2021-6-24]. ISSN 0312-5963. Dostupné z: doi:10.1007/s40262-012-0020-y

[2.] KANTASIRIPITAK, Wannee, Ruth VAN DAELE, Matthias GIJSEN, Marc FERRANTE, Isabel SPRIET a Erwin DREESEN. Software Tools for Model-Informed Precision Dosing: How Well Do They Satisfy the Needs? Frontiers in Pharmacology [online]. 2020, 11 [cit. 2021-7-23]. ISSN 1663-9812. Dostupné z: doi:10.3389/fphar.2020.00620

\section{Kontakt}

Ing. Jiří Potůček, CSc.

Evropská 655/116, 16000 Praha 6

tel: 777166515

e-mail:jiri.potucek@mediware.cz 